\title{
Students' Perceptions on Principle of Risk Management and Insurance as a Blended Learning Course
}

\author{
Nor Mariyah Abdul Ghafar, Nur Faezah Jamal
}

\begin{abstract}
The diversity of education has encouraged the incorporation of technology in education. While classroom learning is still relevant, incorporating an electronic learning (e-learning) to a course will encourage interactive learning experience. This incorporation of face-to-face classroom learning and e-learning is known as blended learning. Thus, the objective of this study is to examine students' perceptions in learning Principle of Risk Management and Insurance as a blended learning course. This study was conducted among Part 1 students of Diploma in Actuarial Science, Universiti Teknologi MARA, Perak Branch, Tapah Campus who took Principle of Risk Management and Insurance which is a blended learning course by using questionnaire. This study proven the findings from previous researches that suggested a combination of traditional classroom learning and online learning is preferred by most students. From students' perspective, it also depicts that blended learning offers more benefits to them and will have a positive impact on their motivation and performance to better understand the course offered.
\end{abstract}

Keywords: Blended learning, e-learning, face-to-face learning, online learning, perception.

\section{INTRODUCTION}

The diversity of education has encouraged the incorporation of technology in education. While traditional education focus on face-to-face learning, technology makes it possible for students to learning anytime at anywhere without face-to-face interaction. While classroom learning is still relevant, incorporating an electronic learning (e-learning) to a course will encourage interactive learning experience. This incorporation of face-to-face classroom learning and e-learning is known as blended learning.

According to [1], e-learning is a means of education that incorporates electronic equipment and tools and the interactivity that occurs between these. Supported by [2], the use of latest technology means that one no longer needs to be located in a conventional classroom to be educated.

Most universities now also encourage the use of technology in teaching and learning due to the rapid development of information technology in education. Since students nowadays have easy access to electronic devices such as handphone, laptop, and iPads, realizing e-learning in education is easy. Thus, the objective of this study is to examine students' perceptions in learning Principle of Risk Management and Insurance as a blended learning course.

\section{PAPER THEORETICAL FOUNDATION}

As we are living in a world that open to the intense change of technology, most higher institutions always search for a better way in delivering knowledge from lecturers as the instructors to their students as the learners. In recent years, many studies have been conducted and published to examine the perceptions of students as the end users in adopting technology in their education. This is important since users' perceptions will affect the success or failure of e-learning and blended learning.

Study by [3] specifically examine students' opinions towards e-learning. The researcher investigated the awareness and willingness of students to use e-learning tools and examined the perceptions and challenges faced by them. Furthermore, in [4] evaluated students' perceptions towards e-Learning Management System (e-LMS) in pharmacy education by conducting a cross-sectional survey. In [5] also examined students' perceptions of e-learning in higher education as a supplement to teacher-controlled tuition on campus through a questionnaire.

Moreover, in [6] has conducted a comprehensive look at blended learning and investigated issues surrounding technology in the classroom among their freshmen students by completing a survey. In addition, in [7] has also identified that newer teaching method like blended learning incorporated in the dental medical education should be evaluated in comparison to traditional lecture format. The responds collected through a Likert survey and interview reported some very positive opinions among students thus supports the merits of incorporating blended learning in dental education curricular. In [8], [9] also investigated the effects of combining online teaching platform with traditional instruction in teaching and learning mathematics. The blended learning pedagogy applied in their education environment revealed that the blended learning experience benefitted students by having a positive impact in improving students' learning outcomes and encouraging them to be more motivated in the blended learning environment.
Revised Version Manuscript Received on September 16, 2019.

Nor Mariyah Abdul Ghafar, Faculty of Computer and Mathematical Sciences, Universiti Teknologi MARA, Perak Branch, Tapah Campus, Malaysia.

Nur Faezah Jamal, Faculty of Computer and Mathematical Sciences, Universiti Teknologi MARA, Perak Branch, Tapah Campus, Malaysia. 


\section{METHODOLOGY}

\section{A. Research design}

This study was conducted among Part 1 students of Diploma in Actuarial Science, Universiti Teknologi MARA, Perak Branch, Tapah Campus who took Principle of Risk Management and Insurance which is a blended learning course. A questionnaire was designed which consists of Part A and Part B. There are two main online learning platforms used while conducting this course namely Massive Open Online Course (MOOC) and i-Learn (an online teaching platform of UiTM). A total of 90 students have responded to the questionnaire.

\section{B. Data collection method}

The approach used to collect data in this study is through a structured questionnaire. The questionnaire was designed into two parts. Part A concentrated on the demographic profile of the students as the respondents while Part B focusing on the perceptions of the students on Principle of Risk Management and Insurance as a blended learning course. There are 4 close ended item questions in Part A whereas Part B consists of 13 close ended item questions. The answers for the questions are organized into 4-point Likert Scale which are strongly disagree (SD), disagree (D), agree (A), and strongly agree (SA).

\section{RESULTS AND DISCUSSION}

The results of this study are represented in Table 1 and Table 2 .

Table 1: Demographic profile of the students

\begin{tabular}{|c|c|c|c|c|}
\hline No. & Category & & Frequency & Percentage \\
\hline \multirow{2}{*}{1} & \multirow{2}{*}{ Gender } & Male & 23 & 74.4 \\
\hline & & Female & 67 & 25.6 \\
\hline \multirow{4}{*}{2} & \multirow{4}{*}{$\begin{array}{l}\text { Sijil Pelajaran Malaysia (SPM) } \\
\text { Results }\end{array}$} & $1-3 \mathrm{As}$ & 25 & 27.8 \\
\hline & & 4-6 As & 42 & 46.7 \\
\hline & & 7-9 As & 22 & 24.4 \\
\hline & & $>9 \mathrm{As}$ & 1 & 1.1 \\
\hline \multirow{4}{*}{3} & \multirow{4}{*}{ Previous School } & Sekolah Menengah Kebangsaan (SMK) & 45 & 50 \\
\hline & & Boarding School & 17 & 18.9 \\
\hline & & Maktab Rendah Sains MARA (MRSM) & 16 & 17.8 \\
\hline & & Others & 12 & 13.3 \\
\hline \multirow{2}{*}{4} & \multirow{2}{*}{$\begin{array}{l}\text { Is this your first time to have a } \\
\text { blended learning course/s? }\end{array}$} & Yes & 64 & 71.1 \\
\hline & & No & 26 & 28.9 \\
\hline
\end{tabular}

Table 1 shows the demographic profile of the students who have responded to the questionnaire. Among the total of 90 students, 23 are male while 67 of them are female. Since this course is a first semester course, all of the students did not have experience learning in tertiary education previously. While most of them got between 4 to 6 As in their Sijil Pelajaran Malaysia (SPM) examination, half of them came from Sekolah Menengah Kebangsaan (SMK) which generally conduct teaching and learning in a traditional way of face-to-face classroom learning. This could lead to the reason why more than half of them have the first-time experience in a blended learning environment while taking this course.

Table 2 summarizes the perceptions of the students on their blended learning experience while taking this course. More than $63 \%$ of the students agree that the course activities arranged were interesting. They felt motivated to explore the contents of the course offered. Since online learning enable information to be delivered in a more interactive way, $59 \%$ of them agree and $34.4 \%$ of them strongly agree that they utilized a variety of information sources to explore the problems posed in this course.

In addition, a total of $94.5 \%$ of the students agree and strongly agree that the learning activities helped them in constructing explanations or solutions. This is supported by the next question in which $65.6 \%$ of them agree and $27.8 \%$ strongly agree that reflection on course contents and discussions helped them to understand the fundamental concepts in this class. Meanwhile, $57.8 \%$ agree and $32.2 \%$ strongly agree that the online components of this course effectively reinforced what they have learnt in the face-to-face sessions. They also agree $(62.3 \%)$ and strongly agree $(31.1 \%)$ that they can apply the knowledge they learn in this blended learning course to their work or other non-class related activities.

One of the advantages of blended learning and online learning course is its flexibility in time management because it is not limited to one- or two-hour time constraint like traditional classroom learning. This is reflected by the agreement of the students $(53.3 \%$ agree and $35.6 \%$ strongly agree) that a blended course format help them to manage their time better. This flexibility also made them felt convenient of not having to come to campus as often since $48.8 \%$ of them agree and $35.6 \%$ strongly agree with this statement.

The online platforms used while conducting this blended learning course offer a variety of contents for creating learning activities for students. Since the contents available online means they can be accessed almost anytime at 
anyplace. The respondents also agree with the flexibility of being able to complete the assignments anyplace or anytime (53.3\% agree and $40.1 \%$ strongly agree).

Furthermore, a total of $84.5 \%$ of the students agree and strongly agree that the workload in this course is much lighter compared to other traditional face-to-face course. Given the opportunity, they would take another blended learning course in the future with $55.6 \%$ and $33.3 \%$ agree and strongly agree with this statement respectively. Overall, when asked about their satisfaction with this blended learning course, $35.6 \%$ strongly agree and $57.8 \%$ agree with this statement. Only 6 out of the total 90 students did not agree with this.

Table 2: Students' perceptions on the blended learning experience

\begin{tabular}{|c|c|c|c|c|c|}
\hline \multirow{2}{*}{ No } & \multirow{2}{*}{ Item } & \multicolumn{4}{|c|}{ Level of Agreement * n (\%) } \\
\hline & & SD & D & $\mathbf{A}$ & SA \\
\hline 1 & Course activities were interesting. & $3(3.3)$ & $2(2.2)$ & $57(63.4)$ & $28(31.1)$ \\
\hline 2 & I felt motivated to explore the contents. & $2(2.2)$ & $4(4.4)$ & $55(61.2)$ & $29(32.2)$ \\
\hline 3 & $\begin{array}{l}\text { I utilized a variety of information sources to explore problems } \\
\text { posed in this course. }\end{array}$ & $3(3.3)$ & $3(3.3)$ & $53(59.0)$ & $31(34.4)$ \\
\hline 4 & $\begin{array}{l}\begin{array}{l}\text { The learning activities } \\
\text { explanations/solutions. }\end{array} \\
\text { exelped me construct }\end{array}$ & $3(3.3)$ & $2(2.2)$ & $57(63.4)$ & $28(31.1)$ \\
\hline 5 & $\begin{array}{l}\text { Reflection on course contents and discussions helped me } \\
\text { understand fundamental concepts in this class. }\end{array}$ & $3(3.3)$ & $3(3.3)$ & $59(65.6)$ & $25(27.8)$ \\
\hline 6 & $\begin{array}{l}\text { The online components of this course effectively reinforced what } \\
\text { I was learning in the face-to-face sessions of this course. }\end{array}$ & $4(4.4)$ & $5(5.6)$ & $52(57.8)$ & $29(32.2)$ \\
\hline 7 & $\begin{array}{l}\text { I can apply the knowledge in this course to my work or other } \\
\text { non-class related activities. }\end{array}$ & $3(3.3)$ & $3(3.3)$ & $56(62.3)$ & $28(31.1)$ \\
\hline 8 & A blended course format helps me to manage my time better. & $4(4.4)$ & $6(6.7)$ & $48(53.3)$ & $32(35.6)$ \\
\hline 9 & I felt convenient of not having to come to campus as often. & $5(5.6)$ & $9(10.0)$ & $44(48.8)$ & $32(35.6)$ \\
\hline 10 & $\begin{array}{l}\text { Flexibility of being able to complete assignments } \\
\text { anyplace/anytime. }\end{array}$ & $3(3.3)$ & $3(3.3)$ & $48(53.3)$ & $36(40.1)$ \\
\hline 11 & $\begin{array}{l}\text { The workload in this course is much lighter compared to other } \\
\text { traditional face-to-face course. }\end{array}$ & $4(4.4)$ & $10(11.1)$ & $49(54.5)$ & $27(30.0)$ \\
\hline 12 & $\begin{array}{l}\text { Given the opportunity I would take another blended learning } \\
\text { course in the future. }\end{array}$ & $3(3.3)$ & $7(7.8)$ & $50(55.6)$ & $30(33.3)$ \\
\hline 13 & Overall, I am satisfied with this blended learning course. & $3(3.3)$ & $3(3.3)$ & $52(57.8)$ & $32(35.6)$ \\
\hline
\end{tabular}

This shows a strong positive feedback from the students about this blended learning course.

The findings obtained through this study are supported by previous studies. The research conducted by [10] showed that majority of the students think e-learning is an innovative idea and must be encouraged. The respondents mostly preferred a hybrid learning that combine online learning and face-to-face learning. This will encourage educational institutions in making investment to make e-learning easier to be implemented.

Participants involved in the study conducted by [11] also give a positive feedback supporting the delivery of instruction and training using online learning. However, the study suggests that the integration of online and classroom learning should be carefully planned based on learner characteristics, course content, and learning context.

Additionally, in [12] showed that students preferred mixed mode and web supplemented courses rather than a web dependent course or fully online courses. This support the idea of blended learning implementation in higher education. In [13] also confirmed that students have definite perceptions about online education as it provides flexibility while maintaining a sense of connectivity with their faculty and institution in general.

\section{CONCLUSION}

This study proven the findings from previous researches that suggested a combination of traditional classroom learning and online learning is preferred by most students. From students' perspective, it also depicts that blended learning offers more benefits to them and will have a positive impact on their motivation and performance to better understand the course offered. Thus, the university need to support the idea of blended learning by providing the necessary online modules and e-learning tools. Meanwhile, the lecturers as the instructors should always be prepared equipping themselves with the essential knowledge of e-learning tools for a better teaching and learning experience to be conducted.

\section{ACKNOWLEDGMENT}

The authors would like to express their gratitude to Universiti Teknologi MARA, Perak Branch, Tapah Campus for giving them the opportunity, support, and facilities for this study. We also like to thank the students for their cooperation during this study.

\section{REFERENCES}

1. K. R and M. Vinayak Mahajan, "A study of students' perception about e-learning," Indian J. Clin. Anat. Physiol., 5(4), 2018, pp. 501-507. 
2. O. E. Ajide and C. C. Tik, "A study on the effectiveness of blended learning," $2^{\text {nd }}$ International Conference of Teaching and Learning, 2009, pp. 1-7.

3. S. L. H. Latt, Assessing the awareness and perception of students in using e-learning tools in a tertiary education: A case study on Sunway University Malaysia. Master thesis, Selangor: Universiti Tunku Abdul Rahman, 2012.

4. H. Mohamed Azmi, S. I. Zeehan, S. Fahad, F. Maryam, and A. Hisham, "Assessment of students' perceptions towards e-learning management system (e-LMS) in a Malaysian pharmacy school: A descriptive study," Malaysian J. Public Heal. Med., 12(1), 2012, pp. 14-20.

5. C. Keller and L. Cernerud, "Students' perceptions of e-learning in university education," J. Educ. Media, 27(1-2), 2002, pp. 55-67.

6. CAWG, First year student perceptions of blended learning. CAWG Snapshot report, University of Maryland, 2014.

7. S. Varthis, Students' perceptions of blended learning and its effectiveness as a part of second year dental curriculum. PhD thesis, Columbia University, 2016.

8. Y. W. Lin, C. L. Tseng, and P. J. Chiang, "The effect of blended learning in Mathematics course," Eurasia J. Math. Sci. Technol. Educ., 13(3), 2017, pp. 741-770.

9. A. F. Awodeyi, E. T. Akpan, and I. J. Udo, "Enhancing teaching and learning of Mathematics: Adoption of blended learning pedagogy in University of Uyo," Int. J. Sci. Res., 3(11), 2014, pp. 40-45.

10. R. S. Mamattah, Students' perceptions of e-learning. Master thesis, Sweden: Linköping University, 2016.

11. K. L. Smart and J. J. Cappel, "Students' perceptions of online learning: A comparative study," Journal of Information Technology Education, 5, 2006, pp. 201-219.

12. R. A. Eldeeb, "Students' perceptions to e-learning," IOSR J. Res. Method Educ., 4(3), 2014, pp. 33-36.

13. J. A. Huss and S. Eastep, "The perceptions of students toward online learning at a Midwestern University: What are students telling us and what are we doing about it?," I.E. Inq. Educ., 4(2), 2013, pp. 1-20. 